\title{
Cerebrovascular Diseases
}

No. 1

Clinical Review

1 Swallowing and Stroke. Neurological Effects and Recovery Smithard, D.G. (Ashford)

Original Papers

9 Circulating Adhesion Molecules in Patients with Internal Carotid Artery Stenosis

Okulla, T.; Gass, S.; Böhme, K.; Tiemann, K.; Harbrecht, U.; Klockgether, T.; Pohl, C. (Bonn)

15 Microalbuminuria in Nondiabetic Patients with Acute Ischemic Stroke: Prevalence, Clinical Correlates, and Prognostic Significance

Słowik, A.; Turaj, W.; Iskra, T.; Strojny, J.; Szczudlik, A. (Krakow)

22 Collateral Circulation via the Ophthalmic Artery or Leptomeningeal Vessels Is Associated with Impaired Cerebral Vasoreactivity in Patients with Symptomatic Carotid Artery Occlusion

Hofmeijer, J.; Klijn, C.J.M.; Kappelle, L.J.; van Huffelen, A.C.; van Gijn, J. (Utrecht)

27 SonoVue ${ }^{\circledR}$ (BR1), a New Long-Acting Echocontrast Agent, Improves Transcranial Colour-Coded Duplex Ultrasonic Imaging Droste, D.W. (Münster); Llull, J.B. (Geneva); Pezzoli, C. (Milan); Bogdahn, U. (Regensburg); Kaps, M. (Giessen)

33 Hydroxyethyl Starch for Hypervolemic Hemodilution in Patients with Acute Ischemic Stroke: A Randomized, Placebo-Controlled Phase II Safety Study Rudolf, J. (Köln); on behalf of the HES in Acute Stroke Study Group

42 Endovascular Therapy of Acute Vertebrobasilar Occlusion: Early Treatment Onset as the Most Important Factor

Eckert, B.; Kucinski, T.; Pfeiffer, G.; Groden, C.; Zeumer, H. (Hamburg)

51 Relation between Age and Number of Aneurysms in Patients with Subarachnoid Haemornage

Pleizier, C.M.; Ruigrok, Y.M.; Rinkel, G.J.E. (Utrecht)

Case Report

54 Seizure at Stroke Onset: Should It Be an Absolute Contraindication to Thrombolysis?

Selim, M.; Kumar, S.; Fink, J.; Schlaug, G.; Caplan, L.R.; Linfante, I. (Boston, Mass.)

Short Report

58 Neurovascular Coupling Remains Unaffected by Glyceryl Trinitrate

Rosengarten, B.; Aldinger, C.; Kaufmann, A.; Kaps, M. (Giessen)

Letter to the Editor

61 Interpretation of Increased Anterior Cerebral Artery Flow Velocity on Transcranial Doppler Ultrasound

Park, K.-I.; Kang, D.-W.; Roh, J.-K. (Seoul)

64 Stroke Vignette
No. 2

Editorial

65 The Heart of the Matter

Oppenheimer, S. (Princeton, N.J.)

Review

67 Electrocardiographic Changes in Patients with Acute Stroke: A Systematic Review

Khechinashvili, G.; Asplund, K. (Umea)

Original Papers

77 Determinants of Plasminogen Activator Inhibitor-1 in South Asians with Ischaemic Stroke

Kain, K. (Leeds); Young, J. (Bradford); Bamford, J. (Leeds); Bavington, J. (Bradford); Grant, P.J.; Catto, A.J. (Leeds)

84 Symptom Spread to Contiguous Body Parts as a Presentation of Cerebral Ischemia

Cohen, S.N.; Muthukumaran, A.; Gasser, H.; El-Saden, S. (Los Angeles, Calif.)

90 Insomnia in Ischemic Stroke Patients

Leppävuori, A.; Pohjasvaara, T.; Vataja, R.; Kaste, M.; Erkinjuntti, T. (Helsinki)

98 The Venturi Effect and Cerebrovascular Ultrasound Ritter, M.A. (Münster/Debrecen); Ringelstein, E.B. (Münster)

105 Effects of the Ultrasound Contrast-Enhancing Agent Levovist ${ }^{\circledR}$ on the Detection of Intracranial Arteries and Stenoses in Chinese by Transcranial Doppler Ultrasound

Hansberg, T. (Hong Kong/Münster); Wong, K.S.L. (Hong Kong); Droste, D.W.; Ringelstein, E.B. (Münster); Kay, R. (Hong Kong)

109 Longitudinal Study of Carotid Atherosclerosis and White Matter Hyperintensities: The EVA-MRI Cohort

Pico, F.; Dufouil, C. (Paris); Lévy, C. (Massy); Besançon, V. (Paris); de Kersaint-Gilly, A. (Nantes); Bonithon-Kopp, C. (Dijon); Ducimetière, P. (Villejuif); Tzourio, C.; Alpérovitch, A. (Paris)

116 Burden of Acute Stroke and Hospital Resources in the Campania Region of Italy

de Falco, F.A.; Santangelo, R.; Majello, L.; Marasco, G. (Naples)

122 Sexual Functioning in Chinese Stroke Patients with Mild or No Disability

Cheung, R.T.F. (Hong Kong)

Case Reports

129 Noninvasive Monitoring of Hypertensive Breakthrough of Cerebral Autoregulation in a Patient with Acute Ischemic Stroke

Georgiadis, D.; Schwarz, S. (Heidelberg); Cencetti, S. (Florence); Schwab, S. (Heidelberg)

133 Cerebral Occlusive Artery Disease in Noonan Syndrome Wilms, H.; Neubauer, B.; Deuschl, G.; Zunker, P. (Kiel)

136 Pure or Predominantly Sensory Transient Ischemic Attacks Associated with Posterior Cerebral Artery Stenosis Kim, J.S. (Seoul)

139 Follow-Up Examinations by Transcranial Doppler Ultrasound in Primary Angitis of the Central Nervous System Ritter, M.A.; Dziewas, R.; Papke, K.; Lüdemann, P. (Münster)

\section{KARGER}

Fax + 41613061234 E-Mail karger@karger.ch www.karger.com (c) 2002 S. Karger AG, Base

Access to full text and tables of contents, including tentative ones for forthcoming issues: www.karger.com/ced issues 
No. 3-4

\section{Original Papers}

143 Hemodynamic Flow Pattems Evaluated by Transcranial Color-Coded Duplex Sonography after STA-MCA Bypass for Internal Carotid Artery Occlusion

Umemura, A.; Yamada, K.; Masago, A.; Kanda, Y.; Matsumoto, T.; Shimazu, N. (Nagoya)

148 Overshoot and Undershoot: Control System Analysis of Haemodynamics in a Functional Transcranial Doppler Test Rosengarten, B.; Osthaus, S.; Kaps, M. (Giessen)

153 Atherothrombotic Risk Factors in Subjects with a Family History of Stroke Lansbury, A.J.; Grant, P.J.; Catto, A.J. (Leeds)

161 High Incidence Rates of Stroke in Örebro, Sweden: Further Support for Regional Incidence Differences within Scandinavia Appelros, P. (Örebro/Stockholm); Nydevik, I.; Seiger, Å. (Stockholm); Terént, A. (Uppsala)

169 Characteristics of Elderly People Readmitted to the Hospital during the First Year after Stroke. The Göteborg 70+Stroke Study

Claesson, L.; Gosman-Hedström, G. (Göteborg); Lundgren-Lindquist, B. (Melbourne); Fagerberg, B.; Blomstrand, C. (Göteborg)

177 'Footprints' of Transient Ischemic Attacks: A Diffusion-Weighted MRI Study

Ay, H.; Oliveira-Filho, J.; Buonanno, F.S.; Schaefer, P.W.; Furie, K.L.; Chang, Y.C.; Rordorf, G.; Schwamm, L.H.; Gonzalez, R.G.; Koroshetz, W.J. (Boston, Mass.)

187 Diffusion-Weighted Imaging in Acute Stroke - A Tool of Uncertain Value?

Fiehler, J. (Hamburg); Fiebach, J.B. (Heidelberg); Gass, A. (Heidelberg-Mannheim); Hoehn, M. (Cologne); Kucinski, T. (Hamburg); Neumann-Haefelin, T. (Frankfurt); Schellinger, P.D. (Heidelberg); Siebler, M. (Düsseldorf); Villringer, A. (Berlin); Röther, J. (Hamburg); for the 'Kompetenz Netzwerk Schlaganfall'

197 Antithrombotic Therapy in Patients with Any Form of Intracranial Haemonhage: A Systematic Review of the Available Controlled Studies

Keir, S.L.; Wardlaw, J.M.; Sandercock, P.A.G. (Edinburgh); Chen, Z. (Oxford)

207 Management and Outcome of Non-Traumatic Cerebellar Haemornhage

Cohen, Z.R.; Ram, Z.; Knoller, N.; Peles, E.; Hadani, M. (Tel Aviv)

214 Dynamic Single-Section CT Demonstrates Reduced Cerebral Blood Flow in Acute Intracerebral Hemornhage

Rosand, J. (Boston, Mass.); Eskey, C. (Lebanon, N.H.); Chang, Y

Gonzalez, R.G.; Greenberg, S.M.; Koroshetz, W.J. (Boston, Mass.)

221 CT Pattems and Long-Term Outcome in Patients with an Aneurysmal Type of Subarachnoid Hemonhage and Repeatedly Negative Angiograms

Ruigrok, Y.M.; Rinkel, G.J.E.; van Gijn, J. (Utrecht)

228 Cognitive Functions and Depression as Predictors of Poor Outcome 15 Months after Stroke

Pohjasvaara, T. (Helsinki/Lohja); Vataja, R.; Leppävuori, A.; Kaste, M.; Erkinjuntti, T. (Helsinki)

234 Effects of Dipyridamole and Aspirin on Shear-Induced Platelet Aggregation in Whole Blood and Platelet-Rich Plasma Nakamura, T.; Uchiyama, S.; Yamazaki, M.; Iwata, M. (Tokyo)

239 Fiblast (Trafermin) in Acute Stroke: Results of the EuropeanAustralian Phase II/ III Safety and Efficacy Trial

Bogousslavsky, J. (Lausanne); Victor, S.J.; Salinas, E.O.; Pallay, A (Philadelphia, Pa.); Donnan, G.A. (Heidelberg, Vic.); Fieschi, C. (Rome); Kaste, M. (Helsinki); Orgogozo, J.-M. (Bordeaux); Chamorro, A. (Barcelona); Desmet, A. (Paris); for the European-Australian Fiblast (Trafermin) in Acute Stroke Group

252 Effect of Increasing Doses of Aspirin on Platelet Aggregation among Stroke Patients

Gan, R.; Teleg, R.A.; Florento, L.; Bitanga, E.S. (Manila)
Case Report

256 Cardiac Papillary Fibroelastoma as a Cause of Recurrent Ischemic Strokes: The Diagnostic Value of Serial Transesophageal Echocardiography

Baba, Y. (Fukuoka); Tsuboi, Y. (Jacksonville, Fla.); Sakiyama, K.; Nakajima, M.; Fjino, Y. (Fukuoka); Meschia, J.F. (Jacksonville, Fla.); Yamada, T. (Fukuoka)

Short Reports

260 No Evidence for Microembolism in Clustering Transient Ischemic Attacks

Batista, P.; Soares, F.; Oliveira, V.; Ferro, J.M. (Lisbon)

261 Central Poststroke Pain in a Consecutive Cohort of Stroke Patients

Weimar, C.; Kloke, M. (Essen); Schlott, M. (Geldern); Katsarava, Z.; Diener, H.-C. (Essen)

Letters to the Editor

264 Isolated Ischemic Third-Nerve Palsy as a Waming Sign of Severe Intemal Carotid Artery Stenosis

Mahagne, M.-H.; Dunac, A.; Bedoucha, P.; Chatel, M. (Nice)

265 Chronobiology of Cerebral Vein and Dural Sinus Thrombosis Ferro, J.M. (Lisbon); Lopes, G.C.; Rosas, M.J. (Porto); Araújo, C. (Lisbon); Henriques, I. (Évora)

266 Recurrent Thromboembolism, Adenocarcinoma and Antiphospholipid Syndrome Kim, J.S.; Choi, E.J. (Seoul)

267 Disclosure of Paradoxical Brain Embolism in Two Stroke Patients with Ultrasound Test for Right-to-Left Shunt and Diffusion-Weighted MRI

Jauss, M.; Schleime, C.; Hügens-Penzel, M.; Traupe, H.; Kaps, M. (Giessen)

Correspondence

270 Imaging of Stroke Pathology without Predefined Gold Standard

von Kummer, R. (Dresden)

271 Reply to the Paper by von Kummer et al.: Imaging of Stroke Pathology without Predefined Gold Standard

Jaillard, A. (Grenoble)

271 Announcement

272 Stroke Vignette

273 Meeting Report

275 Author Index Vol. 14, 2002

276 Subject Index Vol. 14, 2002 